\section{Here we go again: cider's turn to highlight anomalies in Australia's alcohol taxation system}

\author{
Natacha Carragher, Anthony Shakeshaft \\ National Drug and Alcohol Research Centre, University of New South Wales
}

\section{Christopher M. Doran}

Hunter Medical Research Institute, University of Newcastle, New South Wales

In both absolute and per capita terms, the value and volume of cider sales increased enormously in Australia between 2007 and 2011, ranging from 150 to $188 \%$. These increases dwarfed all other types of alcohol; the only other beverages to increase more than $10 \%$ were the absolute volume of spirits (11.8\%) and wine sales (10.3\%), and the absolute value of spirits sales (13.1\%). Due to such strong growth, the cider market is valued at $\$ 552$ million, with volume sales totalling 57 million litres (see Table 1). ${ }^{1}$

Although cider has a low base in Australia (1.8\% of all alcohol sales in 2011), these figures nevertheless raise the question of $w h y$ the cider market is growing so rapidly. The last beverage type to exhibit such large-scale increases, relative to other beverages, was 'alcopops'. Between 2004 and 2007, alcopops volume sales increased 33\%. ${ }^{2}$ A primary factor behind the increased alcopops sales was a taxation loophole, ${ }^{3,4}$ whereby alcopops were taxed equivalently to full-strength packaged beer (but without the $1.15 \%$ excise-free threshold applied to beer) from 2000 to 2008. In April 2008, the Australian Government closed this loophole, bringing alcopops taxation into line with full-strength spirits. Although a positive step in helping reduce the frequency and quantity of alcopops-related drinking, we argued at the time that focusing on just one loophole, rather than restructuring the alcohol taxation system, would create an incentive for the industry to exploit other loopholes. ${ }^{5}$ Although the phenomenal increase in Australian cider sales could reflect strategic marketing, similar to the UK (e.g. the 'over ice' campaign), it most likely reflects the next iteration of industry efforts to exploit loopholes in Australia's alcohol taxation system.

Traditional cider is taxed at a low rate. Under extant taxation arrangements, traditional cider, wine and fortified wine are subject to an ad valorum tax - Wine Equalisation Tax (WET) - which attracts 23 cents tax per standard drink. Conversely, flavoured cider is taxed equivalently to premixed and unmixed spirits (volumetric tax), is subject to bi-annual consumer price index increases, and attracts 95 cents tax per standard drink. Traditional cider is the third-lowest-taxed alcoholic beverage, after cask wine ( 8 cents/standard drink) and mid-strength draught beer ( 20 cents/per standard drink). Traditional cider thus enjoys a price advantage over beverages with similar alcohol content, ${ }^{6}$ an advantage which is accentuated by WET rebate entitlements exempting boutique cider manufacturers from paying the WET. This rebate is not available to small flavoured cider or premixed spirits producers. Also, in much the same way that manufacturers

Table 1: Sales of alcohol by beverage type in Australia, 2007-2011.

\begin{tabular}{|c|c|c|c|}
\hline & 2007 & 2011 & $\begin{array}{r}\text { Change } \\
2007-2011\end{array}$ \\
\hline \multicolumn{4}{|c|}{ Volume of beverages sold (million litres) } \\
\hline Beer & $1,850.1$ & $1,733.1$ & $-6.3 \%$ \\
\hline Cider/Perry ${ }^{a}$ & 20.9 & 56.5 & $170.3 \%$ \\
\hline RTDs/High-strength premixes & 426.9 & 327.1 & $-23.4 \%$ \\
\hline Spirits & 55.9 & 62.5 & $11.8 \%$ \\
\hline Wine & 483.8 & 533.7 & $10.3 \%$ \\
\hline All alcoholic drinks & $2,837.7$ & $2,712.9$ & $-4.4 \%$ \\
\hline \multicolumn{4}{|c|}{ Volume of beverages (L) sold per capita } \\
\hline Beer & 87.0 & 76.6 & $-12.0 \%$ \\
\hline Cider/Perry & 1.0 & 2.5 & $150.0 \%$ \\
\hline RTDs/High-strength premixes & 20.1 & 14.5 & $-27.9 \%$ \\
\hline Spirits & 2.6 & 2.8 & $7.7 \%$ \\
\hline Wine & 22.8 & 23.6 & $3.5 \%$ \\
\hline All alcoholic drinks & 133.5 & 119.9 & $-10.2 \%$ \\
\hline \multicolumn{4}{|c|}{ Value of beverages sold (AUD\$ million, current prices) } \\
\hline Beer & $13,206.0$ & $12,913.1$ & $-2.2 \%$ \\
\hline Cider/Perry & 191.9 & 552.3 & $187.8 \%$ \\
\hline RTDs/High-strength premixes & $5,623.0$ & $5,565.6$ & $-1.0 \%$ \\
\hline Spirits & $3,959.0$ & $4,476.0$ & $13.1 \%$ \\
\hline Wine & $6,944.7$ & $7,128.7$ & $2.6 \%$ \\
\hline All alcoholic drinks & $29,924.7$ & $30,635.7$ & $2.4 \%$ \\
\hline \multicolumn{4}{|c|}{$\begin{array}{l}\text { Value of beverages sold per capita } \\
\text { (AUD\$ million, current prices) }\end{array}$} \\
\hline Beer & 621.1 & 570.9 & $-8.1 \%$ \\
\hline Cider/Perry & 9.0 & 24.4 & $171.1 \%$ \\
\hline RTDs/High-strength premixes & 264.4 & 246.1 & $-6.9 \%$ \\
\hline Spirits & 186.2 & 197.9 & $6.3 \%$ \\
\hline Wine & 326.6 & 315.2 & $-3.5 \%$ \\
\hline All alcoholic drinks & $1,407.3$ & $1,354.5$ & $-3.8 \%$ \\
\hline
\end{tabular}


developed beer- and wine-based alcopops to circumvent the spiritsbased alcopops tax, the Distilled Spirits Industry Council of Australia claims that cider manufacturers are avoiding paying higher taxes by blurring the boundaries between traditional and flavoured cider products through innovative product development and adaptive marketing. ${ }^{6}$

One potential mechanism for closing this loophole is to increase the tax on traditional cider. However, this will most likely prompt the industry to increase prices incrementally to offset marginal tax loss. For instance, although per capita volume consumption of alcopops decreased by $27.9 \%$ from 2007 to 2011 , value decreased by only $6.9 \%$ (Table 1). Alongside minimal impact on profits, adjusting the tax on cider alone is unlikely to achieve sustained reductions in alcohol consumption: while the alcopops tax resulted in an immediate decline in alcopops sales, some consumers switched to other beverages and 2011 sales data indicate that alcopops sales are once again increasing. ${ }^{1}$ In short, previous experience demonstrates that targeted taxation measures have limited efficacy.

Introducing volumetric taxation, whereby all beverages are taxed based on alcohol content, would be a more efficient alcohol taxation system. The system could be structured to balance the reduction in spillover costs from alcohol misuse against the cost of taxation imposed on low-risk drinkers, and retain the $1.15 \%$ tax-free threshold as a financial incentive for producers to manufacture, and consumers to purchase, lower-strength alcohol products. ${ }^{7}$ A volumetric tax on traditional cider alone would yield $\$ 496$ million in additional revenue from 2012 to $2016,{ }^{6}$ which could be hypothecated for prevention and treatment of alcohol-related harms.

The Henry Review ${ }^{8}$ and the National Alliance for Action on Alcohol support volumetric taxation. However, in 2010 the Australian Government rejected the recommendation, on the basis that the wine industry is undergoing restructuring and experiencing a wine glut. Despite recent reform appeals, no changes to alcohol taxation were outlined in the 2012/13 Federal Budget. If the traditional cider taxation loophole remains, cider volume sales will reach an estimated 146 million litres by 2016 , a market value of $\$ 1.5$ billion, at a compound annual growth rate of $21 \%{ }^{1}$ Volumetric tax offers an efficient way off this merry-go-round.

\section{References}

1. Euromonitor International. Alcoholic Drinks in Australia. Sydney (AUST): Euromonitor International (Australia) Pty Ltd; 2012.

2. Doran CM, Digiusto E. Using taxes to curb drinking: A report card on the Australian government's alcopops tax. Drug Alcohol Rev. 2011;30:677-80.

3. Stockwell T, Masters L, Philips M, Daly A, Gahegan M, Midford R, et al. Consumption of different alcoholic beverages as predictors of local rates of night-time assault and acute alcohol-related morbidity. Aust N Z J Public Health. 1998;22:237-42.

4. Fogarty AS, Chapman S. Framing and the marginalisation of evidence in media reportage of policy debate about alcopops, Australia 2008-2009: Implications for advocacy. Drug Alcohol Rev. 2011;30:569-76.

5. Doran CM, Shakeshaft AP. Using taxes to curb drinking in Australia. Lancet. 2008;372:701-2.

6. Distilled Spirits Industry Council of Australia. Pre-budget Submission 2012-13. Melbourne (AUST): DSICA; 2012.

7. Doran C, Byrnes J, Voc T, Cobaic L, Petrie D, Calabria B. Strengthening the Evidence Base for Volumetric Taxation of Alcohol: The Health and Economic Impacts of Alternative Alcohol Taxation Regimes in Australia. Melbourne (AUST): Victorian Health Promotion Foundation; 2011.

8. Henry Review. Australia's Future Tax System: Report to the Treasurer, Part One: Overview. Canberra (AUST): Commonwealth of Australia; 2010.

Correspondence to: Natacha Carragher, National Drug and Alcohol Research Centre, University of New South Wales, Sydney, NSW 2052; e-mail: n.carragher@unsw.edu.au 